\title{
Thermo-fluid-dynamic modelling of a cold store for cheese maturation
}

\author{
Ferruccio Giametta, Flavio Fucci, Pasquale Catalano, Giovanna La Fianza \\ University of Molise, Faculty of Agriculture, Department of Agriculture, Environment and Food \\ Science, Campobasso, Italy
}

\begin{abstract}
In this study, drying tests on fresh cheeses were carried out in a cold store equipped with a Munters MG90 dehumidifier that controls the humidity of the room air. In this system, the condensation/drainage stage is omitted since the humid room air is directed out of the cold store (process air) and the dried air is introduced by the dehumidifier inside the cold store. Eight air temperature probes were introduced in the store; two probes (HOBO U12-012, 1) HOBO - Onset Computer Corporation, Cape Cod, MA, USA) were also introduced and used to measure relative humidity and temperature together with an anemometer to analyse any changes in thermal and fluid dynamics in the cell environment. COMSOL multiphysics software (Comsol Group, Stockolm, Sweden) was used to simulate the store environment based on the finite elements method. This allowed us to compare and discuss the experimental data collected and the results obtained by the thermo-fluid-dynamic simulation.
\end{abstract}

\section{Introduction}

In drying and ripening processes, which induce water transfer and weight loss, knowledge of the mass transfer mechanisms allows us not only to reduce operating costs but also to improve the quality of the final product (Mohsenin, 1989; Cengel, 1997; Gac, 1997; McMinn and Magee, 1999; Pasini, 1999; Salsilmaz et al., 2000; Vega-Mercado et al., 2001; Ho et al., 2002; May and Perrè P, 2002; Brunetti et al., 2004; Dias et al., 2004; Nogaya et al., 2006; Trujillo et al., 2007). Therefore, mathematical models describing mass and heat transfer processes are necessary to optimise the system used, and to widen our understanding of

Correspondence: Giovanna La Fianza, University of Molise, Faculty of Agriculture, Department of Agriculture, Environment and Food Science, via De Sanctis, 86100, Campobasso, Italy.

E-mail: lafianza@unimol.it

Key words: air velocity, water loss, relative humidity, drying, modelling.

Received for publication: 4 October 2012.

Accepted for publication: 16 January 2012.

(C) Copyright F. Giametta et al., 2012

Licensee PAGEPress, Italy

Journal of Agricultural Engineering 2012; XLIII:e26

doi:10.4081/jae.2012.e26

This article is distributed under the terms of the Creative Commons Attribution Noncommercial License (by-nc 3.0) which permits any noncommercial use, distribution, and reproduction in any medium, provided the original author(s) and source are credited. the process in order to better control any undesirable effects. Since it is essential to understand the mechanisms involved, many authors have proposed models to predict moisture distribution during drying (Markowski, 1997; Frias et al., 2002; Hernàndez-Pérez et al., 2004; Bon et al., 2007; Clemente et al., 2007; Riahi et al., 2007; Lertworasirikul and Saetan, 2010).

Numerous commercial software packages have been developed that use the finite elements method. Among these, the COMSOL Multiphysics $^{\mathrm{TM}}$ (version 3.5, Comsol Group, Stockolm, Sweden) was used in this study. The COMSOL is an application package that aims to model and to simulate every type of describable physical process through partial differential equations, solving them through appropriate numerical methods. In particular, it is designed for solving problems of turbulent fluid flow coupled with heat and mass transfers in a given geometry by the use of a mesh where all the Navier-Stokes transport equations are solved across each mesh cell by means of an iterative procedure requiring specific algorithms. In this study, application of computational fluid dynamics is used to improve understanding of the dynamics of maturation tests on fresh cheeses in a maturation cold store in our laboratory equipped with an absorbing dehumidifier, and thus help to optimise existing equipment and design new solutions.

The thermal simulation was carried out taking into account the experimental data obtained and described below. The store was set up with two different regulations of temperature and relative humidity. Steady-state fluid-dynamic conditions were considered to be the trend of the air velocity inside the room when affected only by fan speed and its effective area. We simulated air velocity field showing the zones where a greater turbulence is created.

\section{Materials and methods}

\section{Experimental measurements}

Experimental tests were carried out on a laboratory drying system that consisted of a cold store (Figure $1 \mathrm{~A}$ and $\mathrm{B}$ ) containing a Munters MG90 dehumidifier (Munters AB, Kista, Sweden) that controls the humidity of the room air. In this system, the condensation/drainage stage is omitted since the humid room air is directed out of the cold store (process air) and the dried air is introduced by the dehumidifier inside the cold store.

The refrigeration system prevents any rise in temperature. In this case, the temperature of the cold battery is maintained at a level above the dew point to avoid vapour condensation and the relative humidity of the room being compromised. In this system, the temperature and relative humidity are controlled independently leading to significant benefits. In fact, this system has a positive impact on the amount of electrical energy consumed during the refrigeration process because less power is required and the system is actively working for a shorter time than a traditional refrigeration system. The following process parameters were fixed before starting up the drying system: i) daily loss of weight both as a percentage and as the absolute value relative 
to the intake load of the cold store; ii) daily dehumidification cycles; (a dehumidification cycle is composed of an active period and a pause period of the dehumidifier); iii) dehumidifier capacity during the pause and process cycles; iv) length of the dehumidification period which must be planned for every cycle.

In order to measure the temperatures in the cold store, eight silverplated copper probes (model DLE090 with Pt100 sensing element, LSI Lastem, Milan, Italy) were used. These probes were set at a temperature of $80^{\circ} \mathrm{C}$. Two HOBO U12-012 probes (HOBO - Onset Computer Corporation, Cape Cod, MA, USA) were also used to measure relative humidity (RH) and temperature in the same place. A hot wire anemometer was used to measure the absolute velocity of the air inside the cold store. Previous probes were connected to the data logger BABUC A [Babuc - LSI-Lastem, Settala (MI), Italy] to analyse the thermal and fluid dynamic response of the room environment.

The drying tests of the cheese products were carried out with two different sets of temperature and $\mathrm{RH}$ :

$$
\begin{gathered}
\mathrm{T}_{\min }=12^{\circ} \mathrm{C}, \mathrm{T}_{\max }=13^{\circ} \mathrm{C}, \mathrm{RH}_{\max }=70 \% \text {, duration: } 16 \mathrm{~h} \\
\mathrm{~T}_{\text {min }}=9.5^{\circ} \mathrm{C}, \mathrm{T}_{\text {max }}=11.5^{\circ} \mathrm{C}, \mathrm{RH}_{\max }=90 \% \text {, duration: } 28 \mathrm{~h}
\end{gathered}
$$

The regulation of the room was verified through both measurement and simulation.

Five samples of 4 cheeses were used to evaluate weight loss over time (Figure 2).

In the first phase, which corresponds to the first test (duration $16 \mathrm{~h}$ ), we set up a minimum RH of $65 \%$ and a maximum $\mathrm{RH}$ of $70 \% ; \mathrm{T}_{\min }=12^{\circ} \mathrm{C}$ and $\mathrm{T}_{\max }=13^{\circ} \mathrm{C}$. The temperature probes, numbered from 1 to 8 , were positioned as shown in Figure 3A, while the anemometer was placed in the middle of the store, at a height of $115 \mathrm{~cm}$ from the floor. A Hobo sensor was placed on the floor of the store in the middle of the central carriage. At the end of the first 16 -h period, the samples were weighed. In the second phase, which corresponds to the second, third and fourth tests, we set up a minimal RH of $85 \%$, a maximum RH of $90 \%$ and a temperature range from a $\mathrm{T}_{\min }=9.5^{\circ} \mathrm{C}$ to a $\mathrm{T}_{\max }=11.5^{\circ} \mathrm{C}$, for a total trial duration of $28 \mathrm{~h}$. For the second test, the temperature probes were placed as shown in Figure 3B and the anemometer was placed at a height of $23 \mathrm{~cm}$ from the floor.

A first Hobo sensor was positioned in correspondence with the center low sample, and the second near the Munters dehumidifier. During the third test, the Hobo and the temperature probes were kept in the same position. The only variation occurred in the location of the anemometer that was positioned at a distance of $50 \mathrm{~cm}$ from the lateral panel. In the fourth and final tests, the Hobos were positioned in correspondence with the lateral carriage: the first on the floor and the second lined up with the lateral low sample. The anemometer was positioned at a distance of $5 \mathrm{~cm}$ from the lateral panel. Except for probe no. 4, which was kept in the same position throughout all the tests, the temperature probes were placed on the lateral panels and on the front wall of the cell (Figure 3C). Probe ns. 2 and 5 were fixed in the centre of the left and of the right lateral panels, respectively, at a height of $130 \mathrm{~cm}$, at a distance of $60 \mathrm{~cm}$ from the front wall.

In this study we used scamorza, a spun paste cheese produced in southern Italy. It is obtained from pasteurised cow milk and has a pearlike shape with a prominent and distinct head on the tip; this is formed by the rope that is used to hang the cheese during drying. Scamorza has a slight yellow colour, a compact texture, weighs approximately 200 $\mathrm{g}$, and can be commercialised after one day of drying or after a further 15-20 days of maturation. Ths scamorza cheeses used in this study were produced by a small dairy company in southern Italy (Caseificio Molisano L. Barone snc. Vinchiaturo, Campobasso, Italy). Within $1 \mathrm{~h}$ of production, the cheeses were immediately delivered to the laboratory cold store. The scamorza samples were divided into five batches. Three batches were hung on a lateral undercarriage and two batches on a central undercarriage.

Weight loss of the cheese was periodically evaluated on 10 samples from each batch using an electronic balance (AND GF-1200-EC, precision $0.01 \mathrm{~g}$ ). Colour was determined on the surface of scamorza using the Hunter $L^{*}, a^{*}, b^{*}$ system with a reflectance spectrophotometer (Minolta CR300b, Suita-shi, Osaka, Japan). The results were expressed

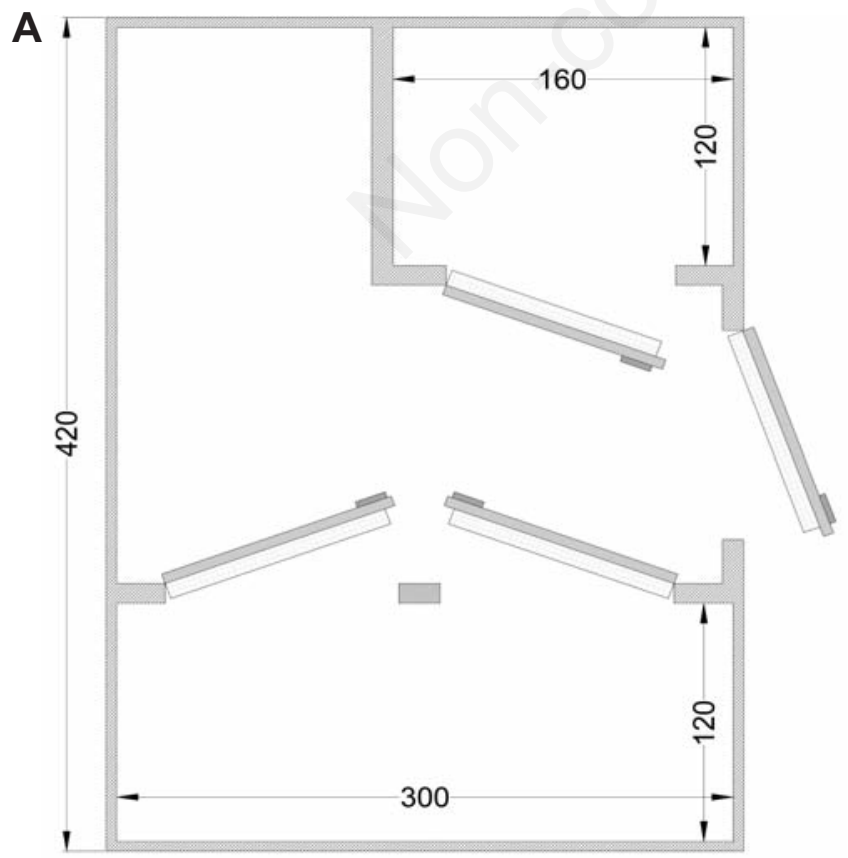

B

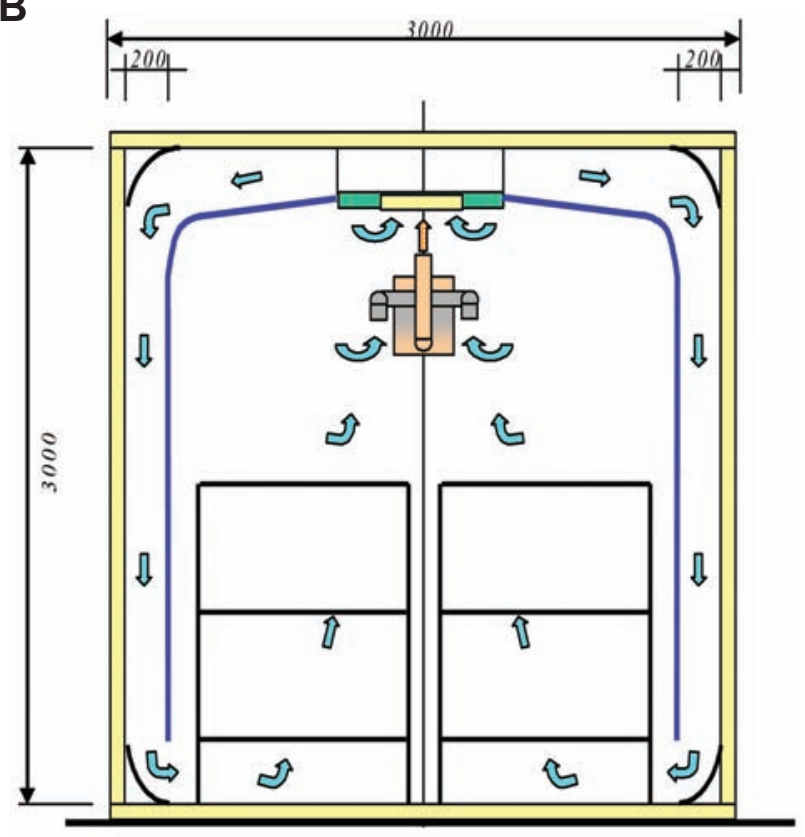

Figure 1. A) Plan of the cell; B) Air circulation in the cell. 
as the mean of three tests performed on different parts of 6 samples for each batch. An untrained panel of 12 judges assessed the sensory properties of the scamorza cheeses. Characteristics evaluated were: inner aspect, outer aspect and flavour. The cheese samples were served at room temperature.

The daily weight loss is related to the number of cycles and to the dehumidification capacity, given the process time of the dehumidifier. Another parameter that influences the drying process of cheese is the geometry of the product; scamorza has a good surface to volume ratio that facilitates the drying procedure. The correct management of this parameter will result in optimal product quality (Vega-Mercado, 2001; Ho, 2002) and a uniform weight loss. The daily weight loss is related to the number of cycles and to the dehumidification capacity, given the process time of the dehumidifier (Gac, 1997; Girard, 1999; Fiameni and Esposti, 2000).

\section{Simulation parameters}

In the steady-state simulation, attention is focused both on the fluid dynamic and thermal conditions of the system when it reaches thermal equilibrium. $\mathrm{k}$ - model was used for fluid dynamic simulation as this is the most appropriate turbulence model for industrial applications due to a sufficiently high Reynolds number and turbulence equilibrium in boundary layers. Water mass transfer and consequent latent heat were not included since heat transfer from walls is the dominant mechanism at regime (steady-state) operations. Mesh was generated by partitioning the domain into approximately 600,000 tetrahedral mesh elements leading to a degree of freedom of over 4 million. To solve the model, a flexible generalised minimum residual method was used coupled with a geometric multigrid preconditioner.

In general, heat conductivity is the main material property useful for a steady-state analysis. In our case, the following parameters were set out for the cheese:

thermal conductivity $\mathrm{k}=0.37 \mathrm{Wm}^{-1} \mathrm{~K}^{-1}$;

density $\rho=1140 \mathrm{kgm}^{-3}$;

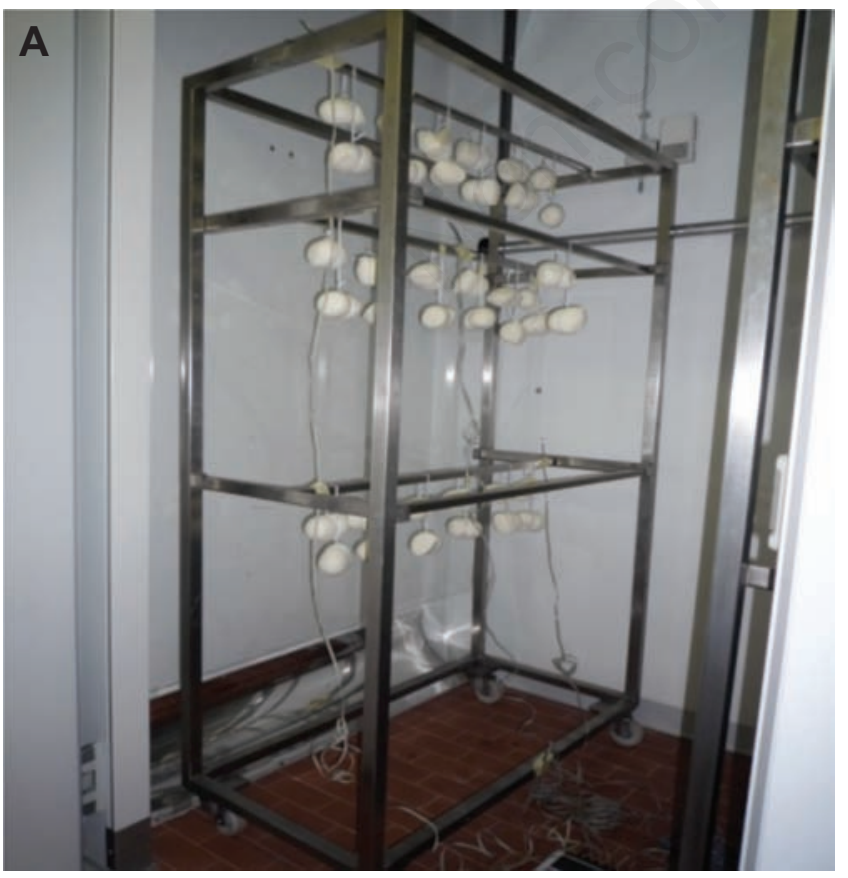

specific heat (constant pressure) $c_{p}=3300 \mathrm{Jkg}^{-1} \mathrm{~K}^{-1}$;

starting temperature value $\mathrm{T}=288 \mathrm{~K}$ air inside cell (standard values at $\mathrm{T}=288 \mathrm{~K}, \mathrm{P}=101.3 \mathrm{kPa}$ where applicable): thermal conductivity $\mathrm{k}=0.026$ $\mathrm{Wm}^{-1} \mathrm{~K}^{-1}$

density $\rho=1.225 \mathrm{kgm}^{-3}$;

specific heat (constant pressure) $c_{p}=1005 \mathrm{Jkg}^{-1} \mathrm{~K}^{-1}$; dynamics viscosity $\eta=0.0000179 \mathrm{~Pa}$ s;

velocity of the air exiting the evaporator $\mathrm{v}=1.5 \mathrm{~ms}^{-1}$; starting temperature value $\mathrm{T}=288 \mathrm{~K}$;

temperature of the air exiting the evaporator $=283 \mathrm{~K}$.

\section{Results and discussion}

The trend of the weight loss is shown in Figure 4.

The colorimetric indices showed an increase in the index of yellow (b) during the maturation of the scamorza cheeses: 16.59 at time 0 . However, a substantial difference in colour was noticeable between central and lateral batches. In detail, after $44 \mathrm{~h}$ of maturation, batch $\mathrm{L}$ had a higher intensity of yellow $(b=21.30)$ compared to batch $\mathrm{C}$ $(b=19.57)$. This is very interesting if we consider that this index is of particular importance in driving consumer choice. The sensory analysis has shown the judges to prefer the cheeses from batch L, especially as regards outer aspect and flavour (data not shown). The samples showing the greatest weight loss were those positioned in the central part of the cell where, as shown later, the greater turbulence of the air occurs and removes higher quantities of water from the products. In the first test $\left(\mathrm{T}_{\min }=12^{\circ} \mathrm{C}\right.$ and $\left.\mathrm{T}_{\max }=13^{\circ} \mathrm{C}\right)$, average temperature values slightly under the minimal settled value were found. In the second and third tests, the average temperature, remaining in the set-up range, was considered to be acceptable. In the fourth test (probes on the front walls), the smallest average values were logged by probes 2 and 5 , located on the left and on the right lateral panels, respectively, In fact, as

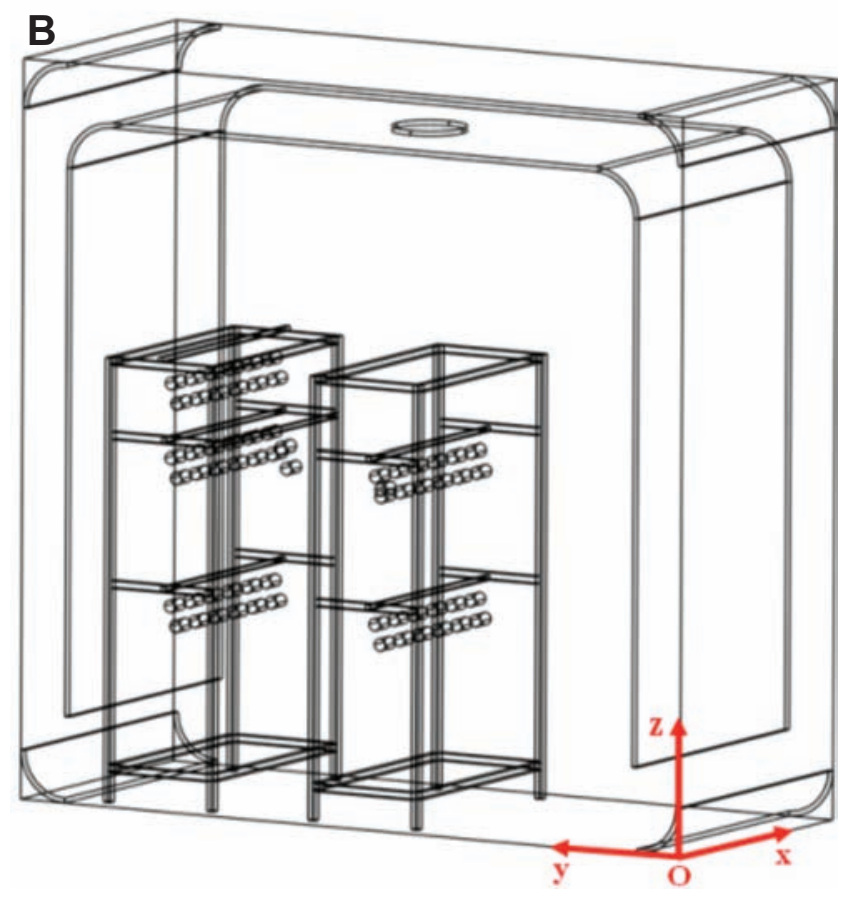

Figure 2. A and B) Samples of cheeses in the cell and simulation scheme: undercarriages, cell and samples. 
expected, these were, in fact, the colder surfaces as they are constantly in contact with the air coming from the cold battery. The temperature is slightly higher (probe $8 \mathrm{~T}=10.7^{\circ} \mathrm{C}$ ) on the front wall of the cell, probably due to the fact that the cheese products were positioned relatively close to it. The medium RH logged by the Hobo was lower with respect to the minimal RH set up. The mean velocity and its standard deviation were also evaluated during each test. Results are shown in Table 1, where $h$ is the height of the anemometer from the floor and $d$ the distance from the left lateral panel. It highlights the fact that the central area of the cell, where the anemometer has been located to a height of $23 \mathrm{~cm}$ from the ground, shows a zone of high turbulence development as it is located underneath and perpendicular to the incoming air flow from the dehumidifier. Results from the fluid-dynamic simulation of the cold store are in accordance with those obtained by the anemometer during the experi During the first and the second tests, concerning a section perpendicular to the $y$ axis and located at a distance of $150 \mathrm{~cm}$ from the origin, it could be noted that at a height of $115 \mathrm{~cm}$ there is a velocity value of $0.06 \mathrm{~ms}^{-1}$. During the second test, the anemometer was located at a height of $23 \mathrm{~cm}$ from floor (Figure 5) and there was a discrepancy between the results and the experimental data.

The simulation shows a velocity of $0.06 \mathrm{~ms}^{-1}$ but the anemometer logged a mean e of $0.21 \mathrm{~ms}^{-1}$. Nevertheless, it can be noted that a few centimetres from the position of the anemometer the velocity value increases, exceeding $0.1 \mathrm{~ms}^{-1}$. Probably the anemometer has not been located in the right position, or there could be a higher computational inaccuracy considering that a high air turbulence occurs inside the highlighted zone. During the third test, the experimental data show a mean of $0.13 \mathrm{~ms}^{-1}$. The anemometer has been located at a distance of $50 \mathrm{~cm}$ from the left lateral panel and at a height of $23 \mathrm{~cm}$. The experimental data provided a mean of $0.13 \mathrm{~ms}^{-1}$. During the simulation, a section was drawn and a mean velocity of $0.11 \mathrm{~ms}^{-1}$ was found in correpondence with the probe position. During the last test, the anemometer was located at a distance of $5 \mathrm{~cm}$ from the left lateral panel, logging a mean velocity of $0.15 \mathrm{~ms}^{-1}$ in accordance with that obtained by the simulation. Figure 6 shows the flux lines of the velocity field and the absolute value of the velocity on two vertical planes. It was noted that the flux lines are centred around the central carriage; this corresponds to a higher weight loss of the cheeses located in that position with respect to the others located on the lateral carriage (Giametta et al., 2012).

The thermal simulation was carried out taking into account the experimental conditions of the second regulation of the cell: $\mathrm{T}_{\min }=$ $9.5^{\circ} \mathrm{C}$ and $\mathrm{T}_{\max }=11.5^{\circ} \mathrm{C}$. Table 2 shows the comparison between the experimental data and the simulation for each section.

Considering a section parallel to the $x$ - $y$ plane (positioned at a distance of $1 \mathrm{~cm}$ from the floor), a temperature of approximately $11^{\circ} \mathrm{C}$ is computed near the lateral carriage, in accordance with the experimental data logged by the Hobo sensor during the fourth test. Considering

Table 1. Velocity and standard deviation (100 samples) related to the position of the anemometer.

\begin{tabular}{lcc} 
Position of anemometer & $\begin{array}{c}\text { Mean } \\
\text { velocity }\left(\mathrm{ms}^{-1}\right)\end{array}$ & $\begin{array}{c}\text { Standard } \\
\text { deviation }\left(\mathrm{ms}^{-1}\right)\end{array}$ \\
Cell centre $(\mathrm{h}=115 \mathrm{~cm})$ & 0.06 & 0.06 \\
Cell centre $(\mathrm{h}=23 \mathrm{~cm})$ & 0.21 & 0.14 \\
\hline Lateral $(\mathrm{d}=50 \mathrm{~cm} ; \mathrm{h}=23 \mathrm{~cm})$ & 0.13 & 0.09 \\
Lateral $(\mathrm{d}=5 \mathrm{~cm} ; \mathrm{h}=23 \mathrm{~cm})$ & 0.15 & 0.13 \\
\hline
\end{tabular}

A

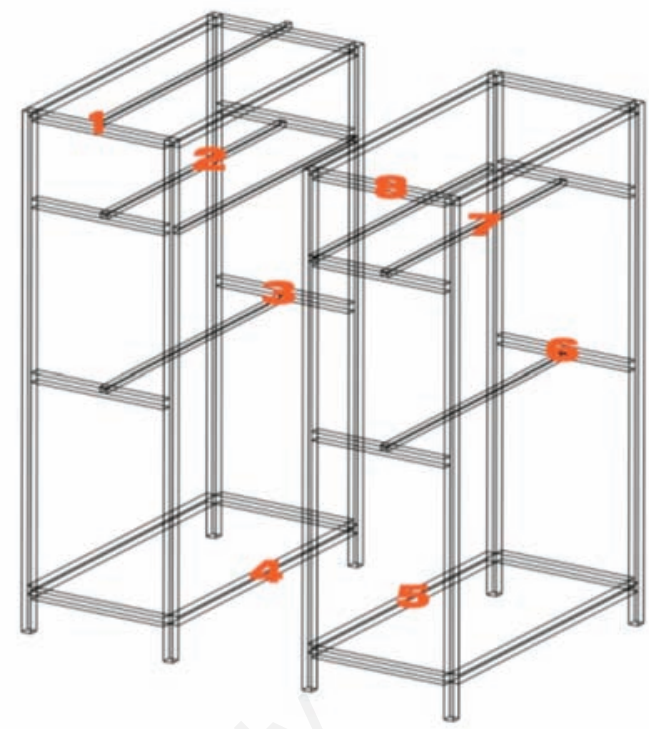

B

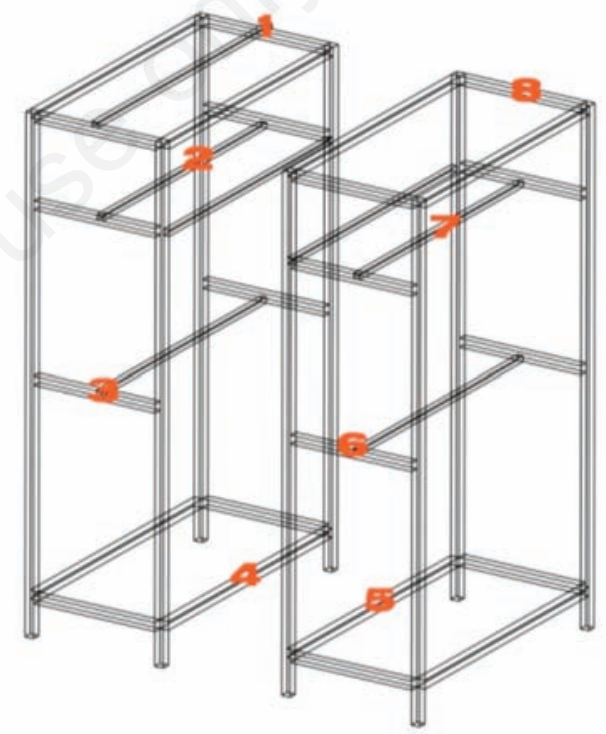

C

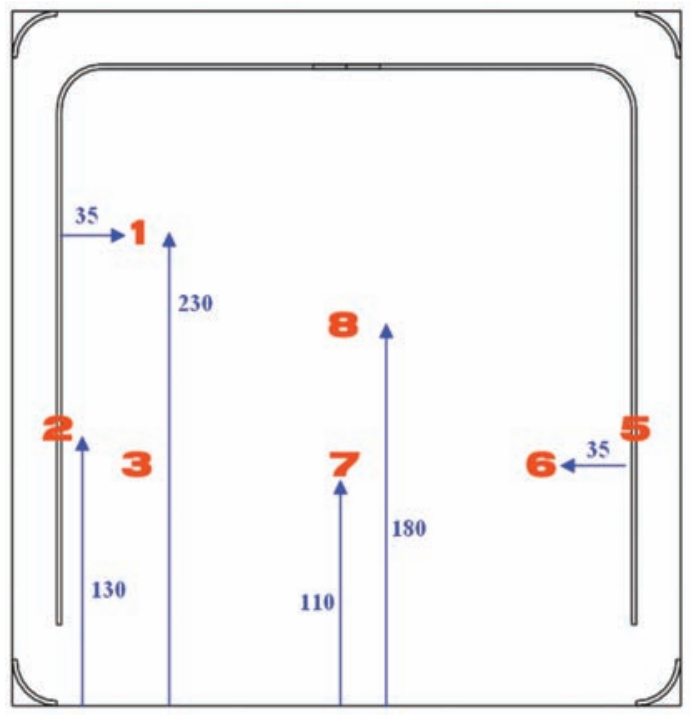

Figure 3. A and B) Temperature probe positions; C) Temperature probe positions. 
Table 2. Comparison between the experimental data and the simulation.

\begin{tabular}{lcccc} 
Section & Hobo-probe & Test & Experimental data & \\
1 & Hobo4th & $\mathrm{mT}=11^{\circ} \mathrm{C}$ & $\mathrm{T}=11^{\circ} \mathrm{C}$ & Simulation \\
2 & Hobo + probes no. $3-6$ & $2^{\text {nd }-3} 3^{\text {rd }}$ & $\mathrm{mT}=10^{\circ} \mathrm{C}$ & $\mathrm{T}=10^{\circ} \mathrm{C}$ \\
\hline 3 - Lateral carriage & Probe no. 1 & $2^{\text {nd }}-3^{\text {rd }}$ & $\mathrm{mT}=10^{\circ} \mathrm{C}$ & $\mathrm{T}=10^{\circ} \mathrm{C}$ \\
3 - Central carriage & Probe no. 8 & $2^{\text {nd }}-3^{\text {rd }}$ & $\mathrm{mT}=10.4-10.2^{\circ} \mathrm{C}$ & $\mathrm{T}=10.7-10.8^{\circ} \mathrm{C}$ \\
\hline
\end{tabular}

$\mathrm{mT}$, mean temperature; $\mathrm{T}$, temperature.

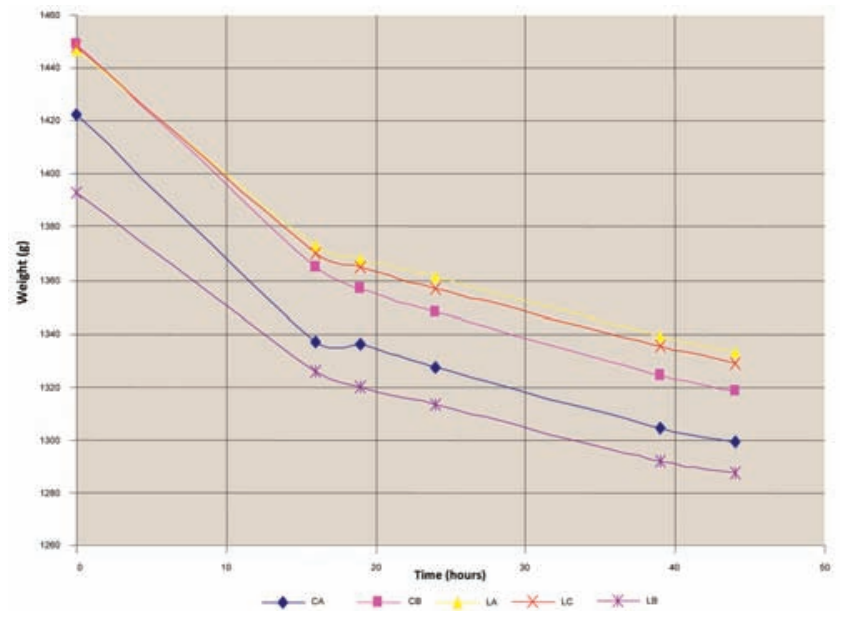

Figure 4. Trend of weight loss.
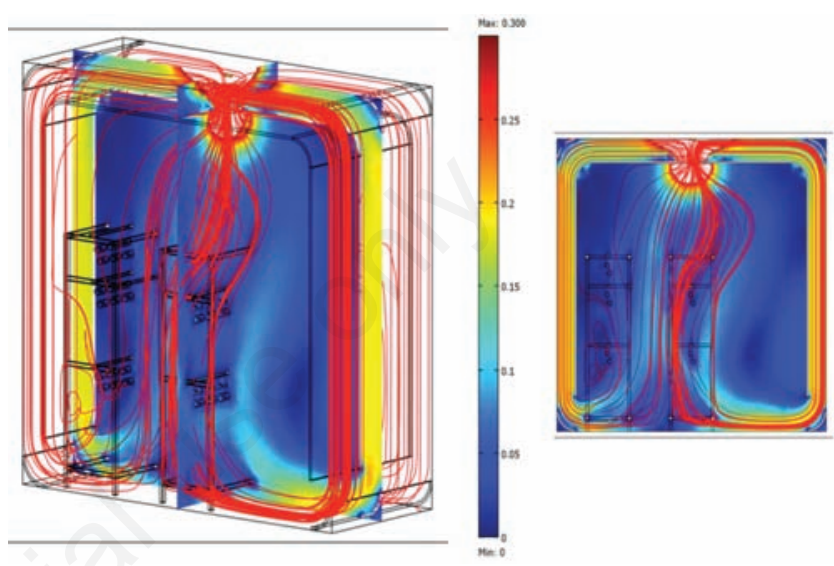

Figure 6. Simulated velocity field.

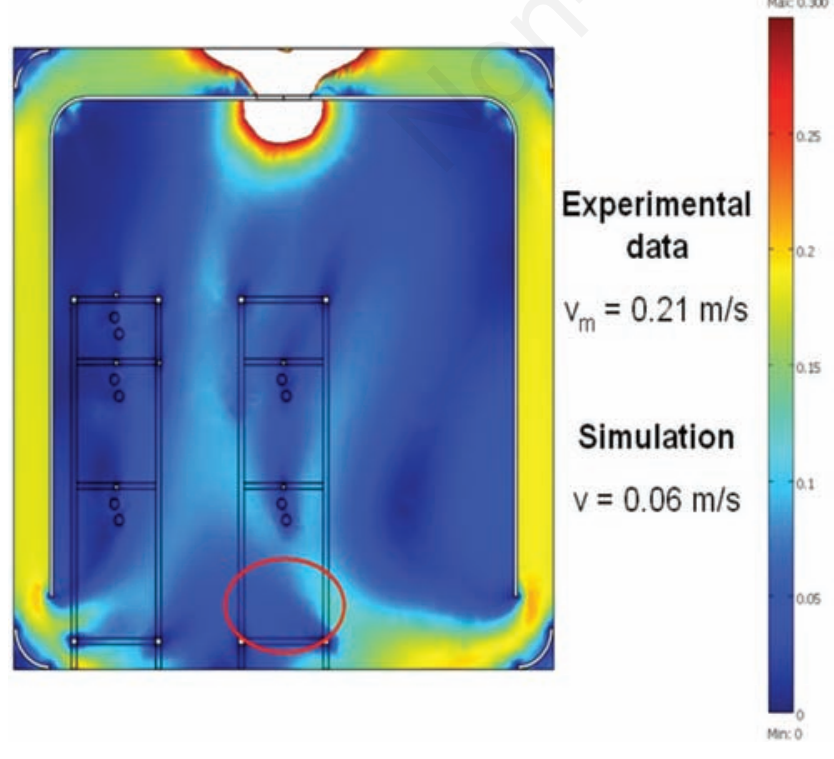

Figure 5. Experimental and simulated velocity values.

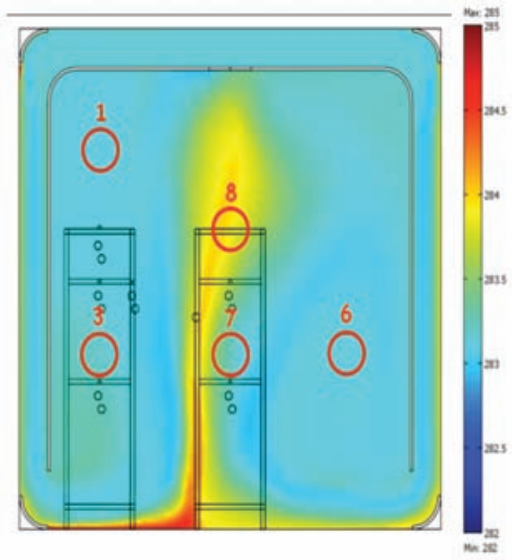

Experimental data

$T_{m}(h=180 \mathrm{~cm})=10.7^{\circ} \mathrm{C}$

(probe 8)

$T_{m}(h=110 \mathrm{~cm})=$

$10-10.2-10^{\circ} \mathrm{C}$

(probes 3.6.7)

$T_{m}(h=230 \mathrm{~cm})=11.2^{\circ} \mathrm{C}$

(probe 1)

Simulation

$T(h=180 \mathrm{~cm})=10.7-10.8^{\circ} \mathrm{C}$

$T(h=110 \mathrm{~cm})=10^{\circ} \mathrm{C}$

$T(\mathrm{~h}=230 \mathrm{~cm})=10^{\circ} \mathrm{C}$ 
a section parallel and positioned at a distance of $90 \mathrm{~cm}$ from the $x-y$ plane, we considered the experimental data logged by the temperature probes no. 3 and 6 and by the Hobo sensors. The simulation gives a temperature of approximately $10^{\circ} \mathrm{C}$, in accordance with the experimental data.

Considering a section positioned at a height of $180 \mathrm{~cm}$, a small difference in temperature is seen next to the carriages. The simulation gives a temperature of $10^{\circ} \mathrm{C}$, in accordance with the n.1 sensor during the second and the third tests. The temperature is slightly higher in the zone near the central carriage $\left(\mathrm{T}=10.7^{\circ} \mathrm{C}\right)$. The sensor n. 8 shows a mean temperature that varies from $10.4^{\circ} \mathrm{C}$ to $10.2^{\circ} \mathrm{C}$ during the second and the third tests, respectively. These values can be compared with those obtained by the simulation. During the fourth test, the measured and computed temperatures on the front wall and of the lateral panels are compared. In particular, a temperature of $10^{\circ} \mathrm{C}$ on the lateral panels was obtained by simulation, with very little discrepancy between the mean temperatures logged by the $\mathrm{n} .2$ and $\mathrm{n} .5$ sensors: $9.5^{\circ} \mathrm{C}$ and $9.8^{\circ} \mathrm{C}$, respectively.

The mean temperature measured by the probe on the left zone of the front wall are slightly higher (simulated: $\mathrm{T}=11^{\circ} \mathrm{C}$, measured: $\mathrm{T}=10.7^{\circ} \mathrm{C}$ ) than previous ones. The values logged by probes no. 3,6 and $7\left(10^{\circ} \mathrm{C}, 10.2^{\circ} \mathrm{C}\right.$ and $10^{\circ} \mathrm{C}$, respectively) are also comparable with the data obtained by simulation (Figure 7). The only temperature that differs slightly from that computed with the thermal simulation concerns the value logged by probe no. 1 : a mean of $11.2^{\circ} \mathrm{C}$. This value does not occur during the plotting of the finite element method analysis where a mean of $10^{\circ} \mathrm{C}$ is obtained. This small difference may be due to the air stagnation in the area around probe no. 1.

\section{Conclusions}

As air change rate and temperature are not adequate parameters for characterising the flow field in a cheese maturation room, thermofluid-dynamic simulation of the maturation store was carried out in order to compare experimental and numerical values. Some interesting results were seen concerning thermal and fluid dynamics. The model used was, in fact, validated given the small discrepancy between the experimental results and the simulation data. Using simplified models in the numerical analysis, the usefulness of computational thermofluid-dynamic for assessing the influence of the position of the product on the performance of maturation chambers has been clearly shown. Indeed, an important result of the present study is that we clearly highlighted how different levels in ventilation near whole cheeses might influence weight loss and consequently the quality of the final product.

However, research is still needed to help those working in the industry to design and/or use maturation rooms. Particular attention should be given to the homogeneity of temperature and velocity distribution around cheeses. This will help operators carry out correct maturation controls by monitoring the indoor atmosphere of the chambers, i.e. air velocity, temperature and relative humidity.

\section{References}

Bird R.B., Stewart W.E., Lightfoot E.N. 2006. Transport phenomena. John Wiley and Sons Ed., Hoboken, NJ, USA.
Bon J., Rossellò C., Femenia A., Eim V., Simal S. 2007. Mathematical modeling of drying kinetics for apricots: influence of the external resistance to mass transfer. Dry. Technol. 25:1829-35.

Brunetti L., Fucci F., La Fianza G. 2004. Un impianto di stagionatura a deumidificazione per assorbimento per alimenti. La Termotecnica. LVII:68-71.

Carcel J.A., Garcia-Perez J.V., Riera E., Mulet A. 2007. Influence of highintensity ultrasound on drying kinetics of persimmon. Dry. Technol. 25:185-93.

Cengel A.Y. 1997. Introduction to thermodynamics and heat transfer. McGraw-Hill Ed., New York, NY, USA.

Clemente G., Bon J., Garcia-Perez J.V., Mulet A. 2007. Natural convection drying at low temperature of previously frozen salted meat. Dry. Technol. 25:1885-91.

Fiameni C., Esposti V. 2000. Celle frigorifere. Il Freddo. 54:646.

Frias J.M., Foucat L., Bimbenet J.J., Bonazzi C. 2002. Modelling of moisture profiles in paddy rice during drying mapped with magnetic resonance imaging. Chemical Eng. J. 86:173-8.

Gac A. 1997. Equipements frigoriferiques: automatisme et conception. Lavoissier Te\&Doc, Paris, France.

Giametta F., Sorrentino E., Lapenna A., La Fianza G. 2012. Experimental tests to optimize cheese drying and ripening. Int. J. Agricult. Biol. Eng. 5:74-82.

Hernandez-Perez J.A., Garcia-Alvarado M.A., Trystram G., Heyd B. 2004. Neural networks for the heat and mass transfer prediction durino drying of cassava and mango. Innovative Food Sci. Emerg. Technol. 5:57-64.

Ho J.C., Chou S.K., Chua K.J., Mujumdar A.S., Hawlader M.N.A. 2002. Analytical study of cyclic temperature drying: effects on drying kinetics and product quality. J. Food Eng. 49:271.

Lertworasirikul S., Saetan S. 2010. Artificial neural network modeling of mass transfer durino osmotic dehydration of kaffir lime peel. J. Food Eng. 98:214-23.

May B.K., Perrè P. 2002. The importance of considering exchange surface area reduction to exhibit a constant drying flux period in foodstuffs. J. Food Eng. 54:271-82.

McMinn W.A.M., Magee T.R.A. 1999. Principles, methods and applications of the convective drying of foodstuffs. Food Bioprod. Process. 77:175-93.

Mohsenin N.N. 1989. Physical properties of agricultural materials and food products. Routledge Publ., Taylor and Francis Group, New York, NY, USA.

Nogaya K., Li Y., Jin Z., Fukumuro M., Ando Y., Akaishi A. 2006. Low temperature desiccant-based food drying system. J. Food Eng. 75:71-7.

Pasini A. 1999. Asciugamento delle carni insaccate. Il Freddo. 53:47.

Riahi M.H., Trelea I.C., Leclercq-Perlat M.N., Piacque D., Corrieu G. 2007. Model for changes in weight and dry matter during the ripening of a smear soft cheese under controlled temperature and relative humidity, Int. Dairy J. 17:946-53.

Salsilmaz C., Yildiz C., Pehlivan D. 2000. Drying of apricots in a rotary column cylindrical dryer (RCCD) supported with solar energy. Renew. Ener. 21:117-27.

Taraschi N. 2000. Il freddo e la conservazione degli alimenti. Principi teorici. Il Freddo. 54:62.

Trujillo F.J., Wiangkaew C., Pham Q.I. 2007. Drying modelling and water diffusivity in beef meat. J. Food Eng. 78:74-85.

Vega Mercado P., Gongora-Nieto M., Barbosa-Canovas G.V. 2001. Advances in dehydration foods. J. Food Eng. 49:271. 